\title{
Evaluation of the Effects of Water Stress and Different Levels of Nitrogen on Sugar Beet (Beta Vulgaris)
}

\author{
M. A. Esmaeili \\ Sari Agricultural Sciences and Natural Resources University, Iran \\ Esmaeil Yasari (Corresponding author) \\ Payame Noor University, Sari, Iran. \\ E-mail: e_yassari@yahoo.com
}

Received: September 02, 2010 Accepted: September 17, 2010 doi:10.5539/ijb.v3n2p89

\begin{abstract}
In order to investigate the effects of water stress and different levels of $\mathrm{N}$ fertilizer on yield and water use efficiency in sugar beet (Var. BP) a split plots based on randomized complete block design was carried out with 4 replications in Khorasan Agricultural and Natural Resources Research Center (KANRC) during cropping season in 2006. Water treatments comprising three levels including control (without water stress), initial water stress and continuous water stress as main plots and different amounts of $\mathrm{N}$ fertilizer in 4 levels vis: control (0), 50,100 and $150 \mathrm{Kg}$ net N. ha ${ }^{-1}$ as sub plots were assessed. Analysis of variation showed that effects of water treatments on root yield and gross sugar content was significant (at $1 \%$ level). Different levels of $\mathrm{N}$ also have significant effect on root yield, net and gross sugar percent at $1 \%$ level while didn't influence net sugar yield significantly. Interaction of water and $\mathrm{N}$ wasn't significant for all the traits. Water use efficiency for root (WUEr) and for sugar (WUEs) were significant in irrigation amounts $(P<0.05)$ However, results showed that increased root yield under no water stress conditions with increased $\mathrm{N}$ amount was much more than it in water stress conditions. In terms of root yield, no water stress treatment using $150 \mathrm{Kg}$ Net N.ha ${ }^{-1}$ had the highest yield. But water stress treatment particularly constant water stress, caused the maximum water use efficiency.
\end{abstract}

Keywords: Sugar beet, Water stress, Water use efficiency, N Fertilizer

\section{Introduction}

The optimum water use in agricultural production is especially important as one of the most important environmental factors affecting plant growth and development, particularly in arid and semi-arid regions and weather conditions of Iran (Tohidloo et al., 2005). Due to increasing used water cost and decreased available water in these regions, water stress has been the center of much attention (Winter, 1980). Low irrigation, in which plant is undergone water stress in a special growth step or in whole season, is one of methods to maximize water use efficiency and to raise yield in face of a unit of used water (Kirda, 2002).

Sugar beet is a drought resistant plant that could produce economic yield even with declined irrigation (Winter, 1980). Water requirement of sugar beet cultivation is strongly dependent on weather conditions, irrigation management and growth period, plant density, genotype and nitrogen application (Kuchaki and Soltani, 1995). This crop is one of the highest water consuming plants due to long growth period, with an annual consumption of 350 to $1150 \mathrm{~mm}$ in different regions of world (Allen et al., 1998). Its water requirement is estimated 883 and $762.8 \mathrm{~mm}$ in growth period in Karaj and Mashhad, respectively (Ghalebi, 2001; Rahimiyan and Asadi, 1999).

Ober (2004) considers relative tolerance of sugar beet to drought as one of the important properties for most of arid and semi- arid regions, and stated that recently drought effect has been known as main factor of decreased yield in sugar beet. Nitrogen also is of the most important elements in sugar beet production, in some cases that the filed was dressed with non-significant nitrogen fertilizer, production extensively reduced, and even in some soils it reduced to half (Cook and Scott,1994). Taleghani et al. (1998) studied effects of water and nitrogen fertilizer on sugar beet. Irrigation levels were 50, 57 and 100\% of plant water requirement and 0, 120, 240 and $360 \mathrm{Kg}$ net N.ha ${ }^{-1}$ were fertilizer treatments. The results indicated that root yield was more by $20 \%$ in $100 \%$ water requirement treatment compared with $50 \%$ treatment but sugar percentage in drier conditions was 
achieved more than wet conditions. Root yield wasn't different significantly in 240 and $360 \mathrm{Kg} \mathrm{N}$ treatments. But it wasn't significant in water treatments.

Almani et al. (1997) reported that water deficit decreased root yield but increased sugar, potassium and Amino N amount and total irrigation increases sugar amount in sugar beet. Ransomanda and Ishida (2006) concluded that water deficit on sugar beet decreased sugar yield and concentration both in early and late season, although significant difference $(P<0.5)$ wasn't observed between intensity effects of early and late season. There was not particular suggestion about the particular growth period which might be more sensitive to water deficit condition. Gencolan and Ucan (2004) by considering 6 irrigation levels, studied water stress deficit on sugar amount, sugar yield and root yield of sugar beet. In irrigation level $1\left(\mathrm{I}_{1}\right)$ when cropping rows received more water, sugar amount, root yield and water use efficiency were more compared with other levels which lower water was received by crop.

Vomucka and Pospisilvoa (2003) reported that water use efficiency in plants under low stress was more than $80 \%$, in mild-stress, 65 to $80 \%$ and in very severe stress below $65 \%$. Carter (1982) expressed that increased $\mathrm{N}$ amount to certain and optimum level, increased root yield, although net and gross sugar amount decreased with increasing $\mathrm{N}$ before root yield reaches to its maximum level. High amount of $\mathrm{N}$ increased sodium, potassium and amino $\mathrm{N}$ concentrations in root. Armestrong et al. (1986) concluded that increased $\mathrm{N}$ in soil increased root yield, $\mathrm{N}$ uptake by plant and also dry mater percentage of root.

\section{Materials and methods}

This research was conducted in Agricultural and Natural Resources Research Center of Khorasan, in 2006. The trial was studied as split plots in randomized complete block design with 4 replications. Three levels of water treatment in main plot including $\mathrm{I}_{1}$ : Irrigation at $50 \%$ of available moisture around the root, (treatment without stress). $\mathrm{I}_{2}$ : Irrigation at $90 \%$ of available moisture around the root and (initial stress or irrigation stress at the first of season after sprouting and settling of plant). $\mathrm{I}_{3}$ : Irrigation at $80 \%$ of available moisture around the root (continuous stress, stress during growth season). Nitrogen fertilizer treatment in sub plot in 4 level including $\mathrm{N}_{1}$ : Control (without fertilizer), $\mathrm{N}_{2}: 50 \mathrm{Kg}, \mathrm{N}_{3}: 100 \mathrm{Kg} \mathrm{N}_{4}: 150 \mathrm{Kg}$ net $\mathrm{N}$ per hectare from ammonium nitrate fertilizer.

Before cultivation, samplings were conducted in order to evaluate the physical and chemical properties of the soil (Tables 1 and 2). Based on these experiments lack of phosphorous and potassium and micronutrients were added. During growth period, moisture was recorded in given time intervals (usually 3 days) in layers of 0-20, 20-40, 40-60 and 60-80 cm with TDR (Time domain reflectometry) instrument. Irrigation time was determined based on these readings. Water depth of irrigation based on the amount of moisture detected from root development area was calculated and each irrigation moisture of soil was filled up till field capacity. Bulk of needed water was estimated according to every main plot area and irrigation was done through Volumetric Counters the amount of used water for treatments were $\mathrm{I}_{1}=12300, \mathrm{I}_{2}=9700$ and $\mathrm{I}_{3}=7100 \mathrm{~m}^{3} \cdot \mathrm{h}^{-1}$. Size of each main plot and sub plot were 80 $\mathrm{m}^{2}$ and $20 \mathrm{~m}^{2}$, respectively, the blocks having a distance of $6 \mathrm{~m}$ from each other.

$<$ Table 1>

$<$ Table 2>

Each sub plot including 4 rows with length of $10 \mathrm{~m}$ was cultivated. Bp Sugar Beet seed cultivar (resistant to drought) from polygerm type were cultivated on rows by row-cultivator instrument on $26^{\text {th }}$ of April. Depth of cultivation was 3 , row intervals were $50 \mathrm{~cm}$ and distances of plants after thinning were $20 \mathrm{~cm}$. basin irrigation method was used and land of trail place was fallow in last year. After complete settlement of the plant and starting plant relative resistance the stress, treatments was applied. Harvesting was started on $16^{\text {th }}$ of November.

Root yield and gross and net sugar yield percentage and water use efficiency (yield for each unit of used water) were measured after harvesting and statistically analyzed. Variance analysis and mean comparisons in Duncan method was done by SAS software (SAS Institute, 2002)

\section{Results and Discussion}

Variance analysis results of studied traits in table 3 show that effect of different water levels on root yield and gross sugar percentage at $1 \%$ level and on water use efficiency at $5 \%$ level was significant. Water levels didn't have any significant affect on net sugar amount, molasses sugar percentage, net and gross sugar yield. Effect of different $\mathrm{N}$ levels on root yield, net and gross sugar percentage was significant at $1 \%$ level. $\mathrm{N}$ levels didn't affect other traits significantly. Water and $\mathrm{N}$ interaction also didn't have significant effect on any of studied traits in this experiment (Table 3 ). 
According to table 3, Duncan mean comparison was done and statistical grouping is given in table 4. Results showed that no water stress level with yield $62.54 \mathrm{t}^{-\mathrm{ha}^{-1}}$ had the maximum yield and after which the initial water stress treatment with the average yield of $52.46 \mathrm{t} \mathrm{ha}^{-1}$ was the second and continuous water stress treatment with yield of 47.54 t.ha ${ }^{-1}$ the third one.

There was not significant different between the levels without water stress and initial water stress but between these two levels and continuous water stress there was a significant difference in terms of yield. Milford (1985) reported that the difference of yield of between different water treatments is related to decreasing pressure potential stomatal conductivity and relative water content of leaf in water stress that cause lower growth of leaves and root because of less development of cells.

Root yield increased with increase in N (Table 3). Lowest root yield was obtained at 0 level of $\mathrm{N}$ per ha (control) with the amount of $50.28 \mathrm{t}^{-\mathrm{ha}^{-1}}$ and the highest was obtained 61.45 with $\mathrm{N}$ level of $150 \mathrm{Kg}$.ha ${ }^{-1}$. As it has been shown in mean comparison tables, there are no significant difference between $0 \mathrm{~N}$ level and 50, 50 and 100, 100 and $150 \mathrm{Kg} \mathrm{N}$ per hectare in view of root yield when compared two by two. Thus $100 \mathrm{Kg} \mathrm{N}$ level per hectare could be more economic in terms of root yield. Kuchaki and Soltani (1996) stated that in early season $\mathrm{N}$ causes increasing number, size and dry mater of leaf and besides to these in late season it causes increasing in root dry mater in area unit. Water stress increased gross sugar percentage. Continues water stress treatment with the amount of $14.72 \%$ located in separate statistical group and there was no significant difference between the levels of initial water stress and without water stress. The amounts of gross sugar percentage in initial water stress treatment and without stress were 14.03 and 13/60, respectively. Kuchaki and Soltani (1996) related the reason of increasing sugar percentage in stress to the lower size of roots (Tubers). The results are similar to Taleghani et al. (1998) and Allen et al. (1998).

As the amount of $\mathrm{N}$ increased gross sugar percentage decreased. Control level $\left(0 \mathrm{~N} \mathrm{Kg.ha}{ }^{-1}\right)$ with $14.86 \%$ gross sugar \% located in separate group statically and there was no significant difference between sugar in levels of 50 , 100 and $150 \mathrm{Kg} \mathrm{N}$. Weeden (2000) related the reduction of sugar percentage with $\mathrm{N}$ increase to the more water preservation in root (Tuber). This result is similar to Carter's results (1982) though it is different with the reports of Taleghani et al. (1998).

Different water levels didn't have significant effect amuont of gross sugar percentage though net sugar percentage increased with water stress. There were significant differences in net sugar percentage between different $\mathrm{N}$ levels, similar to gross sugar percentage of control level $(0 \mathrm{~N} \mathrm{Kg.ha-1})$ with 12.07 net sugar percentage was statistically the first and there other $\mathrm{N}$ levels with $11.14,10.80$ and 10.79\% net sugar stand in second rank (b). Weeden (2000) explained that with increase in soil $\mathrm{N}$ specially in late season amino acid in root increases that it causes sugar crystallization and so reduction of extractable sugar.

$<$ Table $3>$

$<$ Table 4>

Utilizing water stress increased water use efficiency. In continuous stress treatment could produce 6.7 tuber and $0.863 \mathrm{Kg}$ sugar per $\mathrm{M}^{3}$ while initial water stress treatment showed increasing of $6 \mathrm{Kg}$ tuber and $0.675 \mathrm{Kg}$ sugar and in without water stress it was observed $5 \mathrm{Kg}$ for tuber and 0.544 for sugar per $\mathrm{M}^{3}$ used water. The reason of WUE increase in driest conditions, may be this fact that in case of water deficit, the stomatals will become more closed. The stomatal closure affects the exit of water from plant to the atmosphere and the $\mathrm{Co}_{2}$ entrance and the association of dry maters, but its effects are not the same and the exit of water from the plant will be affected more. This causes the denominator of the WUE equation to decrease than its numerator and consequently the amount of WUE will increase. But, there was no difference between water stress levels (Initial and continuous) and initial water stress and without stress level, statistically. There was no significant difference between different $\mathrm{N}$ levels with a view to the amount of WUE statistically. Although results showed that the amount of WUE have been increased by an increase in $\mathrm{N}$ apllication. The results of variance analyziz showed that water and $\mathrm{N}$ interactions on the considered charachteristics were not significant, statistically.

\section{References}

Allen, R., Pereira, L.A. \& Smith, M. (1998). Crop evapotranspiration: guidelines for computing crop water requirement. Irrigation Science., 56, 116-127.

Almani, M.P., Abd-Mishani, C. \& Yazdi Smadi, B. (1997). Drought resistance in sugar beet genotypes. Iranian Journal of Agricutural Research., 28, 15-25.

Armestrong, M.J., Milford, G.F., Pocock, T.O., Last, P.J. \& Day, W. (1986). The dynamics of nitrogen uptake and its remobilization during the growth of sugar beet. Journal of Agricutural Science Camb., 107, $145-154$. 
Carter, J.N. (1982). Effect of nitrogen and irrigation levels, location and year on sucrose concentration of sugar beet in southern Idaho. Journal of American Society Sugar Beet Technol., 21, 86-306.

Cook, D.A. \& Scott, R.K. (1994). The Sugar Beet Crop Chapman \& Hall.

Gencolan, C. \& Ucan, K. (2004). The effect of water deficit on yield and yield components of sugar beet. Turkish Journal of Agriculture, 28, 163-172.

Ghalebi, S. (1999). Water consumption optimization in sugar beet agronomy using water yield production function in Karaj, Iran. Journal of Soil and Water, 12, 20-28.

Kirda, C. (2002). Deficit irrigation practices: Deficit irrigation scheduling based on plant growth stages showing water stress tolerance. http://www.fao.org/docrep/004/Y3655E/Y3655E00.htm.

Kuchaki, A. \& Soltani, A. (1995). Sugar Beet Agronomy. Mashhad University Puplisher.

Milford, G.F.J., Pocock, T.O. \& Riley, J. (1985). An analysis of leaf growth in sugar beet. II: Leaf appearance in field crops. Ann Appl Biol., 106, 163-172.

Ober, E.S., Clark, C.J.A., Lebloa, M., Royal, A., Jaggard, K.W. \& Pidgeon, J.D. (2004). Assessing the genetic resources to improve drought in sugar beet. Agronomic traits of diverse genotypes under droughted and irrigated conditions. Field Crop Res., in press

Rahimiyan, M.H. \& Asadi, H. (1999). Water stress effect on quantitative and qualitative yield of Sugar Beet and determination of production function and its plant coefficient. Journal of Soil and Water, 12, 57-63.

Ransomanda, C.V. \& Ishida, J.K. (2006). Stomatal and non stomatal limitation of photosynthesis under water stress in field- grown grapevines. Australian Journal of Plant Physiology, 421-433.

Taleghani, D., Gohari, J., Tohidloo, Gh. \& Roohi, A. (1998). Final report of studying water and $N$ use efficiency in optimum and stress condition in each sugar beet cultivation arrangement. Sugar Beet Researches Institute.

Tohidloo, G.h., Sadeghian, S.Y., Kashani, A., Gohari, J., Taleghani, D.F. \& Hamdi, F. (2005). Study on water use efficiency, some agronomical and physiological characteristics on the three lines of sugar beet in well watered and stress conditions. Journal of Agronomy and Crop Science, 191, 279-301.

Vomucka, L. \& Pospisilvoa, J. (2003). Rehydration of Sugar Beet plant after water stress. Biology Plant., 46 (1), 57-62.

Weeden, B.R. (2000). Potential of Sugar Beet on the Atherton Tableland. A report for the Rural Industries Research and Development Corporation. www.virdc.gov.au/comp98/npp4.htm-25k

Winter, S.R. (1980). Suitability of Sugar Beet for limited irrigation in a semi-arid climate. Agronomy Journal, $72,118-123$.

Table 1. Soil physical characteristics

\begin{tabular}{|c|c|c|c|c|c|c|c|c|}
\hline \multirow{2}{*}{$\begin{array}{l}\text { Deep } \\
\text { layer } \\
(\mathrm{Cm})\end{array}$} & \multicolumn{3}{|c|}{$\begin{array}{c}\text { Soil particles } \\
(\%)\end{array}$} & \multirow{2}{*}{$\begin{array}{c}\text { Texture } \\
\text { Soil }\end{array}$} & \multirow{2}{*}{$\left(\mathrm{g} / \mathrm{Cm}^{3}\right) \rho_{\mathrm{b}}$} & \multicolumn{3}{|c|}{$\begin{array}{c}\Theta_{\mathrm{v}} \\
(\%)\end{array}$} \\
\hline & Silt & Clay & Sand & & & FC & PWP & $\mathrm{AW}^{*}$ \\
\hline $0-20$ & 58 & 14 & 28 & $\begin{array}{l}\text { Silty } \\
\text { Loam }\end{array}$ & 741 & 27.99 & 12.20 & 15.79 \\
\hline $20-40$ & 54 & 22 & 24 & $\begin{array}{l}\text { Silty } \\
\text { Loam }\end{array}$ & 751 & 29.90 & 12.70 & 17.20 \\
\hline $40-60$ & 50 & 24 & 26 & Loam & 745 & 26.92 & 13.30 & 13.62 \\
\hline $60-80$ & 46 & 18 & 36 & loam & 742 & 23.71 & 9.80 & 13.91 \\
\hline
\end{tabular}

*Available Water 
Table 2. Soil chemical characteristics

\begin{tabular}{ccccccc}
\hline $\begin{array}{c}\text { Deep } \\
\text { layer } \\
(\mathrm{Cm})\end{array}$ & $\mathrm{pH}$ & $\begin{array}{c}\mathrm{P} \\
(\mathrm{PPm})\end{array}$ & $\begin{array}{c}\mathrm{K} \\
(\mathrm{PPm})\end{array}$ & $\begin{array}{c}\mathrm{OC} \\
(\%)\end{array}$ & $\begin{array}{c}\mathrm{EC} \\
(\mathrm{Ds} / \mathrm{m})\end{array}$ & $\begin{array}{c}\mathrm{TN} \\
(\%)\end{array}$ \\
\hline $0-30$ & 8.0 & 7.2 & 154 & 0.27 & 3.71 & 0.44 \\
$30-60$ & 7.9 & 8.0 & 133 & 0.43 & 0.06 & 0.26 \\
\hline
\end{tabular}

Table 3. Variance analysis of traits

\begin{tabular}{cccccccccc}
\hline & & \multicolumn{7}{c}{$(\mathrm{MS})$} \\
\cline { 2 - 9 } S.O.V & Df & $\begin{array}{c}\text { Root } \\
\text { yield }\end{array}$ & $\begin{array}{c}\text { Net } \\
\text { Sugar }\end{array}$ & $\begin{array}{c}\text { Gross } \\
\text { Sugar }\end{array}$ & $\begin{array}{c}\text { Molasses } \\
\text { Sugar }\end{array}$ & $\begin{array}{c}\text { Yield Net } \\
\text { Sugar }\end{array}$ & $\begin{array}{c}\text { Yield Gross } \\
\text { Sugar }\end{array}$ & $\begin{array}{c}\text { Water Use } \\
\text { Efficiency (Sugar) }\end{array}$ & $\begin{array}{c}\text { Water Use } \\
\text { Efficiency (Root) }\end{array}$ \\
\hline R & 3 & 236.852 & 1.166 & 0.563 & 0.187 & 5.218 & 7.047 & 0.125 & 4.312 \\
I & 2 & $962.971^{* *}$ & 3.226 & $5.094^{* *}$ & 0.297 & 6.023 & 9.816 & $0.411^{*}$ & $10.673^{*}$ \\
E & 6 & 92.280 & 1.195 & 0.442 & 0.342 & 2.249 & 2.824 & 0.077 & 1.638 \\
N & 3 & $352.897^{* *}$ & $4.325^{* *}$ & $3.294^{* *}$ & 0.315 & 1.371 & 3.499 & 0.049 & 3.152 \\
I×N & 6 & 175.767 & 1.054 & 0.932 & 0.361 & 2.234 & 3.608 & 0.031 & 1.228 \\
E & 27 & 89.228 & 0.750 & 0.466 & 0.324 & 1.592 & 2.096 & 0.032 & 1.482 \\
\hline
\end{tabular}

**and * significant at the $1 \%$ and $5 \%$ level respectively

Table 4. Effect of water and $\mathrm{N}$ treatments on some characteristics of used in the experiment

\begin{tabular}{cccccccc}
\hline & \multicolumn{7}{c}{ Traits } \\
\cline { 2 - 7 } Treatment & $\begin{array}{c}\text { Root yield } \\
(\mathrm{t} / \mathrm{ha})\end{array}$ & $\begin{array}{c}\text { Net Sugar } \\
(\%)\end{array}$ & $\begin{array}{c}\text { Gross } \\
\text { Sugar } \\
(\%)\end{array}$ & $\begin{array}{c}\text { Yield Net } \\
\text { Sugar } \\
(\mathrm{t} / \mathrm{ha})\end{array}$ & $\begin{array}{c}\text { Yield } \\
\text { Gross Sugar } \\
(\mathrm{t} / \mathrm{ha})\end{array}$ & $\begin{array}{c}\text { Water Use } \\
\text { Efficiency } \\
(\text { Sugar) }\end{array}$ & $\begin{array}{c}\text { Water Use } \\
\text { Efficiency } \\
(\text { Root) }\end{array}$ \\
\cline { 2 - 8 } $\mathrm{I}_{1}$ & $62.54 \mathrm{a}^{*}$ & $10.83 \mathrm{a}$ & $13.60 \mathrm{~b}$ & $6.74 \mathrm{a}$ & $8.45 \mathrm{a}$ & $0.544 \mathrm{~b}$ & $5.07 \mathrm{~b}$ \\
$\mathrm{I}_{2}$ & $58.46 \mathrm{a}$ & $11.06 \mathrm{a}$ & $14.03 \mathrm{~b}$ & $6.46 \mathrm{a}$ & $8.19 \mathrm{a}$ & $0.675 \mathrm{ab}$ & $6.03 \mathrm{ab}$ \\
$\mathrm{I}_{3}$ & $47.54 \mathrm{~b}$ & $11.70 \mathrm{a}$ & $14.72 \mathrm{a}$ & $5.56 \mathrm{a}$ & $6 / 98 \mathrm{a}$ & $0.863 \mathrm{a}$ & $6.70 \mathrm{a}$ \\
$\mathrm{N}_{1}$ & $50.28 \mathrm{c}$ & $12.07 \mathrm{a}$ & $14.86 \mathrm{a}$ & $6.05 \mathrm{a}$ & $7.45 \mathrm{a}$ & 4 & $5.42 \mathrm{a}$ \\
$\mathrm{N}_{2}$ & $52.93 \mathrm{bc}$ & $11.14 \mathrm{~b}$ & $14.01 \mathrm{~b}$ & $5.90 \mathrm{a}$ & $7.37 \mathrm{a}$ & $0.667 \mathrm{a}$ & $5.56 \mathrm{a}$ \\
$\mathrm{N}_{3}$ & $60.06 \mathrm{ab}$ & $10.80 \mathrm{~b}$ & $13.98 \mathrm{~b}$ & $6.44 \mathrm{a}$ & $8.32 \mathrm{a}$ & $0.742 \mathrm{a}$ & $6.32 \mathrm{a}$ \\
$\mathrm{N}_{4}$ & $61.45 \mathrm{a}$ & $10.79 \mathrm{~b}$ & $13.63 \mathrm{~b}$ & $6.63 \mathrm{a}$ & $8.36 \mathrm{a}$ & $0.75 \mathrm{a}$ & $6.42 \mathrm{a}$ \\
\hline
\end{tabular}

*Dissimilar letters is explanatory of significant difference at 5\% level 